\title{
Comorbidities, potentially dangerous and low therapeutic index medications: factors linked to emergency visits
}

\author{
Comorbidades, medicamentos potencialmente perigosos \\ e de baixo índice terapêutico: fatores associados \\ à busca da emergência hospitalar
}

Mariana Younes Tramontina ${ }^{1}$

Maria Beatriz Ferreira ${ }^{2}$

Mauro Silveira de Castro ${ }^{1}$

Isabela Heineck ${ }^{1}$

${ }^{1}$ Programa de Pós-

Graduação em Assistência Farmacêutica, Faculdade

de Farmácia, Universidade Federal do Rio Grande do Sul (UFRGS). Av. Ipiranga 2752, Azenha. 90610-000 Porto Alegre RS Brasil. marianayt@hotmail.com ${ }^{2}$ Departamento de Farmacologia, Instituto de Ciências Básicas da Saúde, UFRGS. Porto Alegre RS Brasil.
Abstract This article aims to investigate the morbidities related to medications, their risk factors and causes detected in patients who seek the Hospital Emergency Service of a University in the South of Brazil. Data collection was based on application of a questionnaire to patients of a minimum age of 18 years, that signing the Term of Free and Informed Consent (TFIC), during the period from October 2013 to March 2014, and analysis of electronic record charts. Cases were evaluated by pharmacists and a doctor to define whether it was a case of medication related morbidity (MRM) and to establish its possible causes. Avoidability of MRM was verified based on criteria previously established in the literature. In total 535 patients were interviewed, and the frequency of MRM was $14.6 \%$, Approximately 45\% of MRMs were related to safety in the use of medications, and approximately $50 \%$ presented user-related questions as the possible cause. Hospitalization was required in 44.8\% of MRM cases; $62.7 \%$ of cases were considered avoidable. Presence of chronic disease and use of potentially dangerous medication and low therapeutic index were considered independent factors associated with development of MRM, according to statistical analysis.

Key words Medication-related morbidity, Medication-related-problem, Hospital emergency, Hospital admissions, Preventability
Resumo $O$ objetivo deste artigo é investigar as morbidades relacionadas a medicamentos (MRM), os fatores e as causas detectados em pacientes que buscam o serviço de emergência de hospital universitário do sul do Brasil. A coleta de dados baseou-se na aplicação de um questionário aos pacientes com idade mínima de 18 anos, durante o período de outubro de 2013 a março de 2014, e na análise do prontuário eletrônico. Os casos foram avaliados para definir se era um caso de MRM e para estabelecer as suas possíveis causas. A evitabilidade da MRM foi verificada com base em critérios previamente estabelecidos na literatura. No total foram entrevistados 535 pacientes e a frequência de MRM foi de 14,6\%. Aproximadamente, $45 \%$ das MRMs foram relacionadas com a segurança no uso de medicamentos e cerca de 50\% apresentou como possível causa questões relacionadas ao usuário. Houve necessidade de internação em 44,8\% dos casos de MRM; 62,7\% dos casos foram considerados evitáveis. Presença de doença crônica e utilização de medicamentos potencialmente perigosos e de baixo indice terapêutico foram consideradas fatores associados ao desenvolvimento de MRM.

Palavras-chave Morbidade relacionada a medicamento, Problema relacionado a medicamento, Emergência hospitalar, Admissão hospitalar, Evitabilidade 


\section{Introduction}

Medications are the most used alternative therapy in clinical practice, and represent a great advancement in the prevention and treatment of diseases ${ }^{1}$. However, the unnecessary or incorrect use of a drug may trigger or aggravate morbidities, compromising the user's quality of life, and even cause death ${ }^{1}$.

Medication-related morbidities are considered a public health problem ${ }^{2-4}$. They are defined as the undesirable clinical result arising from medication therapy used, or lack of it, including adverse of toxic effects and treatment failures ${ }^{5}$.

MRMs have frequently been the cause of persons seeking emergency services. Studies have pointed out rates ranging from approximately 17 to $40 \%{ }^{6-9}$. The morbidities related to the need for and safety of medications are the most cited in cases that lead to admission to hospital ${ }^{10}$.

Any adverse situation that involves medication and has the potential to cause the development of a MRM is denominated a "medication-related problem" (MRP) $)^{11}$. The most common causes involved are untreated or insufficiently treated health problems, adverse reactions, drug interactions and toxicity ${ }^{12}$. Researchers have pointed out that the avoidability of MRM is approximately $70 \%$, and consists of detecting and controlling MRPs ${ }^{13-15}$.

In addition to damage to the user, MRMs generate costs to the health system, because attendance by a doctor, hospitalization or prolonged hospital stay and follow-up of the patient are frequently necessary. Menéndez-Conde et al. ${ }^{16}$ estimated an annual cost of 15.568 .952 with MRMs identified in an emergency service in Spain. In the South of Brazil, Medeiros Netto et al. ${ }^{17}$ observed the mean cost of $1,040.55$ reais per patient hospitalized due to a MRP.

In view of the foregoing, the aim of the present study was to describe the MRMs detected in the emergency service of a University Hospital in the South of Brazil, their causes and associated factors, in order to characterize the problem and subsidize prevention and intervention strategies.

\section{Methodology}

This cross-sectional, quantitative study was conducted in the Urgency and Emergency Service of the "Hospital de Clínicas de Porto Alegre" (HCPA), a hospital school located in the South of Brazil, between the months of October 2013, and
March 2014. This service has 49 beds for adult, and 9 for pediatric patients, and comprises the following assistential areas: Reception, Pediatric and Adult Observation Units, Hospitalization Unit and Vascular Unit.

The participating population consisted of adult men and women of a minimum age of 18 year, who awaited attendance by a doctor after the process of triage and risk classification performed by the nursing team, in accordance with the Manchester Protocol, in the Urgency and Emergency Service of HCPA, during the period of study. The criteria for inclusion of patients in the study were: to be capable of verbal communication, or presence of a companion - family member or caregiver - who demonstrated knowledge about the medications used by the patient; agreeing to sign the Term of Free and Informed Consent (TFIC); going through the complete interview, and having had a medical consultation in the emergency service. Each individual was included only once in the study, irrespective of the number of times he/she had sought the service during the period in which the interviews were held. Informed consent was obtained from all individual participants included in the study.

For sample calculation, national and international studies that had observed the frequency of seeking the hospital emergency service due to medication-related morbidities were consid$\operatorname{ered}^{6,7,12,18}$. Considering the mean number of frequencies of $24.73 \%$, an acceptable error of $9.5 \%$ and confidence interval of $95 \%$, the minimum sample size was 78 patients with suspected medication-related morbidity. The sample calculation was made using the software program Winpepi version 11.1. This was a non-probabilistic convenience sample.

To the patients who agreed to participate in the study, a questionnaire was applied - which had been previously validated ${ }^{19}$, translated to the Portuguese language and adapted to the local reality. The questions contained in it allowed data with reference to the patient's clinical and drug therapy history. The interviews were held from Monday through to Friday, in the morning and/ or afternoon period. Afterwards, the electronic record charts of the patients interviewed were analyzed in order to collect information complementary to that previously obtained, with regard to symptoms, comorbidities, diagnosis and need for hospitalization. To help in the detection of MRM and its possible causes, the history of previous outpatient consultations was used, if available. 
The variables of interest were: age, sex, race, comorbidities present, frequency of seeking attendance by a doctor, educational level, number of medications, medications used in the last 10 days, and need for hospitalizing the patient in the last 90 days.

For evaluation of the cases, the databases, clinical books and protocols were consulted, for better analysis of the information with respect to the medications and diseases presented by patients. When there was a suspected MRM, the clinical situation was evaluated by a second pharmacist; when the doubt persisted, the case was defined by means of a group discussion, with the presence of a doctor.

In the cases of suspected adverse reaction, the Naranjo algorithm was used for evaluation ${ }^{20}$. Cases classified as "doubtful" after application of the instrument, were disregarded.

The MRMs detected were categorized as "evident" or "suspected". The morbidity detected by serum dosage of medications or biologic parameters and complementary exams were considered "evident". They were considered "suspected" when a strong relationship of the medication with a possible causal factor of the clinical situation presented by the patient was verified, however, not backed by objective data. In both situations, the clinical history reported by the patient was evaluated. The morbidities were also classified as problems of need, effectiveness, and safety of the medication, according to the Third Consensus of Granada ${ }^{11}$.

For identification and classification of the MRMs, the algorithm presented by Fernández-Llimós et al. was used, which is based on categorization of the cause of $\mathrm{MRM}^{21}$. In order to determine whether the causes, and consequently, the morbidities detected were avoidable, the instrument developed by Baena et al. ${ }^{2}$ was used.

With regard to the medications used, polymedication was considered exposure to 5 or more medications ${ }^{6,22}$. The medications were classified as having a low therapeutic index (therapeutic dose close to the toxic dose). The RDC 67 published by ANVISA in October 2007 were used for this classification ${ }^{23}$. The medications were also classified as potentially dangerous, based on the list published by the Institute for Safe Medication Practices (ISMP). In 2012, the ISMP published a bulletin citing insulins as part of low therapeutic index group of medications, regardless of the route of administration and packing material ${ }^{24}$.

Descriptive analysis was performed with absolute and relative frequencies, means and stan- dard deviation, calculation of the Chi-square and $\mathrm{T}$ test. Differences with a value of $\mathrm{p}<0.05$ were considered significant.

Univariate analysis was performed to compare the groups with and without MRM detected. The magnitude of the associations was estimated by the Prevalence Ratio (PR), considering the interval of confidence of $95 \%$ (IC95\%). The independent effect of the variables was evaluated by means of multivariate logistic regression. The multivariate model included all the variables statistically associated with the development of MRM in a univariate analysis with a value of $\mathrm{p}<$ 0.20 , in addition to the variables "age $\geq 65$ years" and "gender" which are important predictors for the description of the sample and for comparison with other studies. The data were analyzed in the software Program SPSS version 18.0.

This project was approved to the Ethics Committee of the "Hospital de Clínicas de Porto Alegre".

\section{Results}

In total 553 users of the emergency service of HCPA were interviewed, of whom 18 were excluded due to loss of access to the record chart or because the patient had not had a medical consultation. Thus the results were obtained with the data of 535 individuals. The profile of patients with and without MRM is presented in Table 1.

Among the interviewees, it was identified that $78(14,6 \%)$ sought the emergency service due to a MRM. The majority of these patients (92.3\%) presented some chronic disease. The presence of diabetes mellitus (DM) $(\mathrm{p}=0.041)$, DM associated with systemic arterial hypertension $(\mathrm{SAH})(\mathrm{p}$ $<0,001)$, cardiac insufficiency (CI) $(\mathrm{p}=0.003)$, infection by the human immunodeficiency virus $(\mathrm{p}<0.001)$ and depression $(\mathrm{p}=0.014)$ was significantly higher in the group with MRM.

The most frequent morbidities observed were: complications of diabetes mellitus, such as necrosis of members, ketoacidosis, edema ( 8 cases each), exacerbation of an infectious process, hyperanticoagulation, sleepiness (5 cases each), diarrhea and exacerbation of CPOD symptoms (4 cases each). The biological systems most affected were cardiovascular, skin and mucosa, and gastrointestinal systems (Table 2).

Among the cases of MRM, 52 (66.7\%) were considered suspected, and 26 cases (33.3\%) evident. As regards the classification in accordance with the Third Consensus of Granada, approxi- 
Table 1. Characteristics of patients interviewed and attended at the emergency service.

\begin{tabular}{|c|c|c|c|c|}
\hline Characteristics & $\begin{array}{l}\text { Patients without MRM } \\
\quad(n=457)(\%)\end{array}$ & $\begin{array}{l}\text { Patients w/MRM } \\
\quad(n=78)(\%)\end{array}$ & $\begin{array}{c}\text { Total } \\
(\mathrm{n}=535)(\%)\end{array}$ & $\mathbf{p}$ \\
\hline \multicolumn{5}{|c|}{ ( } \\
\hline Female & $297(64.99)$ & $44(56.41)$ & $341(63.74)$ & 0.184 \\
\hline Male & $160(35.01)$ & $34(43.59)$ & $194(36.26)$ & \\
\hline \multicolumn{5}{|l|}{ Age } \\
\hline 18 to 64 years & $347(75.93)$ & $58(74.36)$ & $405(75.70)$ & \\
\hline 65 years or older & $110(24.07)$ & $21(25.64)$ & $130(24.30)$ & 0.298 \\
\hline \multicolumn{5}{|l|}{ Race } \\
\hline White & $347(75.93)$ & $62(79.49)$ & $409(76.45)$ & 0.556 \\
\hline Black & $103(22.54)$ & $14(17.95)$ & $117(21.87)$ & \\
\hline Mulatto & $7(1.53)$ & $2(2.56)$ & $9(1.68)$ & \\
\hline \multicolumn{5}{|l|}{ Educational level } \\
\hline None & $13(2.84)$ & $4(5.13)$ & $17(3.18)$ & 0.660 \\
\hline Primary school incomplete & $215(47.05)$ & $39(50.00)$ & $254(47.48)$ & \\
\hline Primary school Complete & $105(22.98)$ & $19(24.36)$ & $124(23.18)$ & \\
\hline High school Complete & $103(22.54)$ & $13(16.67)$ & $116(21.68)$ & \\
\hline Complete College & $21(4.60)$ & $3(3.85)$ & $24(4.49)$ & \\
\hline \multicolumn{5}{|l|}{ Origin } \\
\hline Porto Alegre & $270(59.08)$ & $50(64.10)$ & $320(59.81)$ & 0.067 \\
\hline Metropolitan Region & $140(30.63)$ & $20(25.64)$ & $160(29.91)$ & \\
\hline Coastal Region & $4(0.88)$ & $4(5.13)$ & $8(1.50)$ & \\
\hline Interior & $39(8.53)$ & $4(5.13)$ & $43(8.04)$ & \\
\hline Other State/Country & $4(0.88)$ & - & $4(0.75)$ & \\
\hline Presence of chronic disease & $283(61.93)$ & $72(92.31)$ & $55(66.36)$ & $<0.001$ \\
\hline \multicolumn{5}{|l|}{ Medications } \\
\hline $0-4$ medications & $302(66.08)$ & $41(52.56)$ & $343(64.11)$ & \\
\hline 5 or more medications & $155(33.92)$ & $37(47.44)$ & $192(35.89)$ & 0.03 \\
\hline \multicolumn{5}{|l|}{ Risk Classification } \\
\hline White & $31(6.78)$ & $1(1.28)$ & $32(5.98)$ & \\
\hline Green & $1(0.22)$ & $1(1.28)$ & $10(1.87)$ & \\
\hline Blue & $9(1.97)$ & - & $1(0.19)$ & 0.001 \\
\hline Yellow & $314(68.71)$ & $42(53.85)$ & $356(66.54)$ & \\
\hline Orange & $102(22.32)$ & $34(43.59)$ & $136(25.42)$ & \\
\hline Red & - & - & - & \\
\hline Being followed-up at HCPA & $265(57.99)$ & $47(60.26)$ & $313(58.50)$ & $>0.999$ \\
\hline
\end{tabular}

mately $47 \%$ of the MRMs detected were related to safety in the use of medications. Questions related to need and effectiveness comprised approximately $31 \%$ and $24 \%$ respectively.

By verification of the possible causes of MRMs, 38 (48.7\%) were found to be related to questions associated with the patient him/herself, such as: non adhesion to treatment, no follow-up by a doctor, error of administration, use of contra-indicated medications due to self-medication or irrational use. Adverse reactions considered common and resulting from polymedication were related to the medication itself in use in 27 cases $(34.6 \%)$. Problems related to medications were also the consequence of the service provided by the health system $(11.5 \%)$, errors of prescription, unavailability in the supply of the medication, inadequate medical follow-up, lack of guidance, therapeutic inertia.

With regard to the avoidability of the causes, and consequently, the MRMs, 49 (62.8\%) were found to be avoidable, because they concerned situations such as the natural need for optimization of the therapy, cases refractory to treatment or predictable adverse reactions, while the other were not $(37.2 \%)$ (Table 3$)$.

Thirty-four patients with MRM detected required hospitalization, which represents $43.6 \%$ of this population and $6.4 \%$ of the total population. Of these cases $22(64.7 \%)$ were considered avoidable and the mean hospital stay observed was $4.5( \pm 8.5)$ days. In the population in which 
Table 2. The biologic systems affected by the morbidities detected and frequency of drugs involved.

\begin{tabular}{|c|c|c|}
\hline System affected & $\begin{array}{c}\text { Morbidity } \\
\text { detected }\end{array}$ & Drugs/Pharmacological Classes \\
\hline Gastrointestinal & 11 & $\begin{array}{l}\text { ARVT (3), Gemcitabine (1), Capecitabine (1), Fluorouracil (1), } \\
\text { Oxaliplatin (1), Balatacep (1), Mineral Oil (1), Loperamid (1), } \\
\text { Digoxin (1), Sulfametoxazol/Trimetoprima (1), NPH Insulin, } \\
\text { Tramadol (1), Codein (1) }\end{array}$ \\
\hline Skin and Mucosa & $14^{*}$ & $\begin{array}{l}\text { Antimicrobial (1), phenytoin (1), Lamotrigine (1), ARVT not } \\
\text { specified (3), Oral Hypoglycemic drugs (2), Insulin not specified } \\
\text { (3), NPH Insulin (1), Efavirenz (1), Tenofovir (1), without } \\
\text { treatment (1) Sulfametoxazol/Trimetoprima (1), Amoxicillin/ } \\
\text { Clavulanate (1) }\end{array}$ \\
\hline Hematologic System & 10 & $\begin{array}{l}\text { Warfarin (7), AAS (2), Doxorubicin (1), Levonorgestrel/Ethinyl } \\
\text { Estradiol (1), Prednisone (1) }\end{array}$ \\
\hline Central nervous system & 8 & $\begin{array}{l}\text { Carbamazepine (3), phenytoin (1), Enalapril (1), Antihypertensive } \\
\text { medication (1), Flunitrazepam (1), Polymedication (1), Valproic } \\
\text { Acid (1) }\end{array}$ \\
\hline Endocrine System & 4 & Insulin (3), Oral Hypoglycemic drugs (2) \\
\hline Electrolytic Balance & 1 & Sertraline (1) \\
\hline Renal System & 1 & Amitriptyline \\
\hline Cardiovascular System & 15 & $\begin{array}{l}\text { Metoprolol (4), Digoxin (2), Antihypertensive medications not } \\
\text { specified (6), Atenolol (1), Hydrochlorothiazide (1), Enalapril (4), } \\
\text { Clonazepam (1) }\end{array}$ \\
\hline Respiratory System & 7 & $\begin{array}{l}\text { Telaprevir (1), ARVT (2), lack of treatment (2), Formoterol/ } \\
\text { Budesonide (1), Flunitrazepam (1) }\end{array}$ \\
\hline Musculo-Skeletal System & $2^{* *}$ & Topiramate (1), Ergotamine (1) \\
\hline Immunologic System & 1 & Sodium Miycophenolate (1) Tacrolimus (1) \\
\hline Bone System & 1 & Oral Hypoglycemic medications (1) Insulin not specified (1) \\
\hline $\begin{array}{l}\text { Ophthalmological } \\
\text { Medications }\end{array}$ & 4 & $\begin{array}{l}\text { ARVT (1), Oral Hypoglycemic medications (1), Insulin not specified } \\
\text { (1), phenytoin (1), Phenobarbital (1) }\end{array}$ \\
\hline Others & 2 & Analgesic (1) Ferrous Sulphate (1) \\
\hline Total Number of MRMs & 83 & \\
\hline
\end{tabular}

* 3 cases of necrosis resulting from diabetes; other systems may have been affected. ${ }^{* *} 1$ case of thoracic pain; other systems may have been affected. ARVT - Antiretroviral Therapy.

no MRM was detected, the mean time of hospitalization was $3.0( \pm 7.92)$ days. The classes of drugs most involved in the cases that led to hospitalization were: insulins, anticonvulsant, anticoagulant, anti-hypertensive and antiretroviral drugs.

It was found that the group of patients with MRM detected was polymedicated, with the mean number of medications per individual equal to 5.3 ( \pm 3.55$)$. Among these patients, 46 (59\%) used at least 1 potentially dangerous medication (PD) and 37 (47.4\%) at least one medication with a low therapeutic index (LTI).

With regard to medications used by patients who sought the emergency service due to MRM, $22(28.2 \%)$ of the cases were associated with the use of a substance with a low therapeutic index. Among them, those most involved with morbidity were the insulins and wafarin (7) digoxin (3), carbamazepine and phenytoin (2) and valproic acid (1). It was verified that 38 cases (48.7\%) were related to medications said to be potentially dangerous, with the most cited being the antiretroviral drugs (9), Warfarin and insulins (7) and the oral hypogycemic medications (5).

It was found that the group of patients with MRM detected was polymedicated, with the mean number of medications per individual equal to 5.3 ( \pm 3.55$)$. Among these patients, 46 (59\%) used at least 1 potentially dangerous medication (PD) and 37 (47.4\%) at least one medication with a low therapeutic index (LTI). 
Table 3. Frequency of seeking the Hospital de Clínicas de Porto Alegre - Emergency Service due to MedicationRelated Morbidity.

\begin{tabular}{|c|c|c|c|c|}
\hline $\begin{array}{c}\text { MRM } \\
\text { Classification }\end{array}$ & $\begin{array}{l}\text { MRM Frequency } \\
\qquad(\%)(\mathbf{n}=78)\end{array}$ & $\begin{array}{l}\text { Avoidability } \\
(\%)\end{array}$ & Possible Causes & $\begin{array}{l}\text { Number } \\
\text { of cases }\end{array}$ \\
\hline \multicolumn{5}{|l|}{ Need } \\
\hline & $24(30.77)$ & $24(100)$ & Non adhesion to treatment & 13 \\
\hline & & & Problem not treated & 5 \\
\hline & & & Treatment not instituted & 1 \\
\hline & & & No follow-up by doctor & 2 \\
\hline & & & Interruption of treatment by doctor's decision & 1 \\
\hline & & & $\begin{array}{l}\text { Recently manifested problem/did not go to the } \\
\text { doctor }\end{array}$ & 2 \\
\hline & & & Lack of resources to acquire the medication & 1 \\
\hline & & & $\begin{array}{l}\text { Lack of the medication at place where it is } \\
\text { obtained }\end{array}$ & 1 \\
\hline & & & $\begin{array}{l}\text { Patient abandoned medical service without } \\
\text { treatment having been established }\end{array}$ & 1 \\
\hline & & & Adverse reaction to medication & 2 \\
\hline & & & Involuntary use of medication & 1 \\
\hline \multicolumn{5}{|l|}{ Effectiveness } \\
\hline & $27(34.62)$ & $13(48.15)$ & Insufficient treatment & 2 \\
\hline & & & Refractory to treatment & 2 \\
\hline & & & Poor adhesion to treatment & 9 \\
\hline & & & No follow-up by doctor & 3 \\
\hline & & & $\begin{array}{l}\text { Need for higher dose for maintenance of } \\
\text { treatment }\end{array}$ & 2 \\
\hline & & & Need for optimization of therapy & 1 \\
\hline & & & Difficulty in definition of therapeutic dose & 1 \\
\hline \multicolumn{5}{|c|}{ 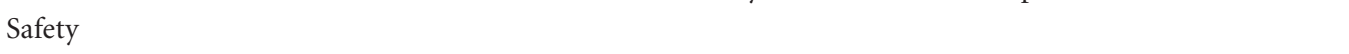 } \\
\hline & $35(44.87)$ & $12(34.28)$ & Error of administration & 2 \\
\hline & & & Adverse reaction & 27 \\
\hline & & & Lack of follow-up by doctor & 1 \\
\hline & & & Use of contraindicated medications & 1 \\
\hline & & & $\begin{array}{l}\text { Administration of higher dose than that } \\
\text { recommended }\end{array}$ & 2 \\
\hline & & & Drug intoxication & 1 \\
\hline & & & Benzodiazepine Dependence & 1 \\
\hline & & & Drug interaction & 2 \\
\hline & & & $\begin{array}{l}\text { Did not have serum dose performed of } \\
\text { medication with narrow therapeutic margin }\end{array}$ & 1 \\
\hline & & & $\begin{array}{l}\text { Prescription of higher dose than that } \\
\text { recommended }\end{array}$ & 1 \\
\hline Total & $78(100)$ & $49(62.82)$ & & $89(100)$ \\
\hline
\end{tabular}

With regard to medications used by patients who sought the emergency service due to MRM, $22(28.2 \%)$ of the cases were associated with the use of a substance with a low therapeutic index. Among them, those most involved with morbidity were the insulins and wafarin (7) digoxin (3), carbamazepine and phenytoin (2) and valproic acid (1). It was verified that 38 cases $(48.7 \%)$ were related to medications said to be potentially dangerous, with the most cited being the antiretroviral drugs (9), warfarin and insulins (7) and the oral hypogycemic medications (5).

In order to analyze which factors contributed to the appearance of MRM, uni- and multivariate analyses were performed, which are presented in Table 4. 
Table 4. Univariate and multivariate analyses of factors associated with development of MRM in patients attended at Hospital de Clínicas de Porto Alegre -Emergency Service.

\begin{tabular}{|c|c|c|c|c|c|c|}
\hline \multirow[t]{2}{*}{ Characteristics } & \multirow[t]{2}{*}{$\begin{array}{c}\text { Patients } \\
\text { without MRM }\end{array}$} & \multirow[t]{2}{*}{$\begin{array}{c}\text { Patients } \\
\text { with MRM }\end{array}$} & \multicolumn{2}{|l|}{$\begin{array}{l}\text { Univariate } \\
\text { Analysis }\end{array}$} & \multicolumn{2}{|c|}{$\begin{array}{c}\text { Multivariate } \\
\text { Analysis }\end{array}$} \\
\hline & & & RP (CI95\%) & $p$ & RP $(\mathrm{CI} 95 \%)$ & $p$ \\
\hline Age $\geq 65$ years old & $110(24.07)$ & $20(25.64)$ & $1.32(0.79-2.18)$ & 0.279 & $0.83(0.47-1.42)$ & 0.490 \\
\hline Gender (Male) & $160(35.01)$ & $34(43.59)$ & $1.42(0.86-2.32)$ & 0.166 & $1.24(0.73-2.10)$ & 0.420 \\
\hline Chronic disease present & $283(61.93)$ & $72(92.31)$ & $7.2(3.31-18.88)$ & 0.279 & $5.12(2.22-13.96)$ & $<0.001$ \\
\hline Previous hospitalization & $110(24.07)$ & $25(32.05)$ & $1.45(0.84-2.44)$ & 0.174 & & \\
\hline $\begin{array}{l}\text { Has frequent medical } \\
\text { consultations }{ }^{*}\end{array}$ & $349(76.37)$ & $62(79.49)$ & $1.54(0.86-2.89)$ & 0.149 & & \\
\hline Polymedication & $155(33.92)$ & $37(47.44)$ & $1.67(1.02-2.73)$ & 0.041 & & \\
\hline Number of medications ${ }^{\star *}$ & & & $1.13(1.05-1.21)$ & 0.002 & & \\
\hline Use of PD Medications & $121(26.48)$ & $46(58.97)$ & $3.85(2.34-6.4)$ & $<0.001$ & $2.01(1.16-3.50)$ & 0.014 \\
\hline Number of PD medications ${ }^{* *}$ & & & $1.77(1.42-2.20)$ & $<0.001$ & & \\
\hline Use of LTI Medications & $56(12.25)$ & $37(47.44)$ & $4.93(2.73-8.83)$ & $<0.001$ & $3.09(1.63-5.81)$ & 0.001 \\
\hline Number of LTI medications ${ }^{\star *}$ & & & $2.93(1.89-4.57)$ & $<0.001$ & & \\
\hline
\end{tabular}

${ }^{*}$ Considered the consultations made frequent, at least, annually. ${ }^{* *}$ Chance of developing MRM with increment of 1 medication in therapy. PD: potentially dangerous. LTI: low therapeutic index.

The results of the univariate analysis indicated that the presence of chronic disease, polymedication and type of medication in use (PD or LTI) had a significant influence on the development of MRM. Age of over 65 years, gender, previous hospitalization and not having a medical consultation did not appear to increase the chance of developing MRM. In this analysis, the increment of one medication in the therapy represented a chance of developing MRM of 1.13 (CI95\%):1.05 $\pm 1.21 ; p=0.002$ ). In the case of the increment of one medication classified as $\mathrm{PD}$, the chance would be 1.77 (CI95\%: $1.42-2.20 ; p \leq 0.001$ ); in the case of a LTI medication, 2.93 (CI95\%: $1.89 \pm$ 4.57; $\mathrm{p} \leq 0.001$ ).

The multivariate analysis allowed one to observe that chronic disease and the use of PD or LTI medications are factors independently associated with the development of MRM.

\section{Discussion}

In this study, the demand for emergency service due to MRM was verified in $14.6 \%$ of the cases and the rate of admission to hospital due to MRM was $6.4 \%$. The presence of chronic diseases, use of potentially dangerous or low therapeutic index medications were characterized as factors associated with the development of MRM. It were identified many causes of MRM, especially adverse drug reaction, non adhesion to treatment and untreated health problems. However, these causes may be avoided, in approximately $60 \%$ of the cases by the action of health professionals.

As the main limitation, the study presents the application of a questionnaire to the users of emergency services, because they are there in the condition of being a patient, and therefore, not all were shown to be fully willing to collaborate. In view of this, one must consider that not all the responses were faithful, and the possibility of uncertainty of the information, seeing that the capacity of the individuals to remember could be diminished. The effect of this factor was minimized by collecting the data on the electronic record charts, in spite of some being very concise, and the use of a period of time of 10 days for the interviewer to remember about medications.

Another question to consider is that an MRM may be the consequence of multiple factors, and probably not all of them were considered in each case, due to the difficulty of obtaining more detailed information. Furthermore, the study design, time and period of data collection (morning and afternoon), which may generate bias, must be considered.

The term normally used in studies that propose to investigate the contribution of medications to health problems identified in emergency services is MRP, which involves manifested and potential problems. Therefore, comparison of the 
frequencies reported, must be done with caution.

A review of prospective studies published on the subject, conducted by Zed ${ }^{25}$, revealed 4 studies that indicated a frequency in the demand for emergency service due to MRP ranging from 4.3 to $28.1 \%$. Al-Arifi et al. ${ }^{26}$ verified a frequency of $18.7 \%$, a value closer to that found in the present study, however, also occurring in MRP. In the study conducted by Andreazza et al. ${ }^{6}$, in the HCPA-E, the frequency of $31.6 \%$ of MRP was verified.

The literature about the topic of MRPs indicates that they are directly associated with the development of morbidity, aggravation of existent diseases, even death, and are the frequent reason for seeking emergency services and the cause of hospitalization. The decision to working with the term MRM was defined, because this conveys damage suffered by the patient, while the term MRP does not necessarily do so.

MRMs are considered a public health problem, because not only do they harm the quality of life of individuals, but they are also a burden to the health system. However, the causes of MRM may be avoided, as confirmed in the study, in approximately $60 \%$ of the cases by the action of health professionals. Therefore, identification of the causes may be a way to prevent possible demands for hospital emergencies or other types of services, and prevent damage to health.

In this study, the rate of admission to hospital due to MRM was $6.4 \%$, similar to the rate cited by other studies ${ }^{26-29}$. This rate may be higher, because the patients classified as "red" were not considered, due to the impossibility of applying the questionnaire to them. In a meta-analysis conducted by Souza ${ }^{30}$, involving 115 studies, the prevalence of hospitalizations due to MRP was 12.1\% (CI95\%: $11.4-16.1 \%$ ) among patients attended in the emergency service. As regards the mean number of days of hospitalization, Martin et al. ${ }^{29}$ related that there was no statistical difference between patients who were admitted due to a MRP and those who were not. In the present study also, no statistical difference was verified as regards the mean number of days of hospitalization between groups with and without MRM ( $p$ $=0.128$ ).

Among the classes of drugs frequently cited as those related to admission to hospital are those that act on the cardiovascular system (including diuretics, cardiotonic glycosides and betablockers), psychotropic, antiplatelet, antiepileptic and hypoglycemic medications, almost the same as those identified in the present study ${ }^{13}$.
Antihypertensive medications were those most involved in MRM, with adverse drug reaction (ADR), non adhesion, therapeutic inertia, and lack of follow-up by doctor being the main causes involved. Antiretroviral, oral hypoglycemic drugs and insulin were related to cases not treated and low adhesion to treatment; many persons that must make use of these medications do not appear to understand the disease and its consequences, or do not accept this condition. As regards anticoagulant drugs, the cause of cases of morbidity were not undergoing periodic control of the anticoagulation level, ADR and drug interactions.

Untreated health problems and low adhesion to treatment were the main causes of MRM classified as of necessity. In spite of the existence of a national program for the dispensing of antiretroviral drugs, this was one of the classes of drugs most involved. A study conducted by Gomes et al. ${ }^{31}$ pointed out alarming results obtained by follow-up of patients under treatment for HIV: $57,9 \%$ of the patients frequently had the acquisition of medications considered irregular, and $30.3 \%$ abandoned the treatment.

Various authors considered polymedication an important factor for the development of $\mathrm{MRM}^{28,32}$. In this study, the univariate analysis showed association between polymedication and morbidity. However, the statistical significance was not maintained in the multivariate model, and polymedication was not considered a factor for the development of MRM. From the cases analyzed, it appears that the type of medication used has a greater influence than the quantity of items, since the so-called PD and LTI medications, also in the multivariate analysis, were significantly involved in the demand for emergency services, increasing the chance of development of MRM by 2.01 and 3.09 times, respectively. This result is important since the increase in life expectancy and the complexity of some treatments contribute to the increase in the number of polymedicated patients. These factors are also involved in the increase in the demand for health services, which increasingly demand that health professionals establish strategies to optimize their work.

Takahashi et al (2011) pointed out the number of comorbidities as a factor associated with the development of MRM, with the prevalence of $35 \%$ of negative results related to medications being observed in patients with 6 or more comorbidities, and $17 \%$ in individuals with up to 3 comorbidities. Diseases that affect the cardiovascular system were those most related to drug-re- 
lated negative outcomes (DNOs), followed by endocrine, metabolic and nutritional diseases diabetes mellitus, dyslipidemia and obesity - and those that affect the central nervous system ${ }^{33}$.

In the present study, the presence of chronic diseases was also considered an important factor for the appearance of MRM ( $\mathrm{PR}=5.12$; CI95\%: 2.22 - 13.96). Diabetes mellitus, hypertension and the two associated diseases represent approximately $55 \%$ of the clinical conditions cited by patients who seek hospital emergency services due to MRM. In the group without MRM detected, they represented approximately $30 \%$.

Hypertensive diabetics are generally polymedicated. Among the patients interviewed, the mean number of medications in use was $7.6( \pm$ 3.9). Huri and $W^{34} e^{34}$ verified a mean of $6.9( \pm$ 2.8) pharmaceutical specialties and $1.9( \pm 1.2)$ MRPs per patient; in total, $90.5 \%$ of the patients presented at least 1 MRP. Together with polymedication, the author cited age, kidney damage and cardiovascular events as factors associated with MRPs, considering that they contribute to the occurrence of ADR and drug interaction, in addition to contributing to a condition unfavorable to the individual.

Among those interviewed, 27.5\% responded that they did not make frequent medical consultations. Nevertheless, this did not appear to be a factor associated with MRM (PR = 1.54; CI95\%: $0.86-2.89)$, and with the prior need for hospitalization (PR $=1.45$; CI95\%: $0.84-2.44)$. An important consideration is that perhaps it is not the number of medical consultations that promotes the prevention of MRM, but the quality of the attendance. According to the WHO, the time suggested for a medical consultation to be adequate is 15 minutes. However, Oenning et al..$^{35}$ observed the time of 5.94 minutes in consultations in primary health care of a municipality close to the one where the present study was conducted.

The morbidities detected were mainly associated with problems related to safety and the need for medication in approximately $45 \%$ and $31 \%$ of cases, respectively. Adverse reaction (28.1\%), non adhesion to treatment $(20.2 \%)$ and untreated health problems $(5.6 \%)$ were the main causes identified. These were also the reasons most related to the cases of hospitalization associated with use of medications. Al-Arifi et al. ${ }^{26}$, in Saudi Arabia, verified the same causes as being the most frequent in seeking the emergency service associated with medication: ADR and non adhesion to treatment both in $30.4 \%$, and untreated health problems in $10.7 \%$ of cases.
In $48.7 \%$ of cases we attributed the responsibility for the development of MRM to the patient, mainly due to the lack of adhesion to treatment. In spite of health professionals not frequently having been held responsible for the development of MRM in this study (11.7\%), they were associated with avoidable errors, which mainly impacted on the safety of patients: drug intoxication, prescription of a dose above the recommended on, not monitoring the medication therapy with a low therapeutic margin, drug interaction, and insufficient guidance.

The question of drug toxicity was present in the results: 3 cases confirmed by serum dosage, 1 involving the medication phenytoín, 1 digoxin, representing $3.8 \%$ of the cases, and 1 of involuntary use of sulfonylurea, which would probably lead to an intoxication due to not needing the medication. In addition to these, 1 case of benzodiazepine dependence (serum dosage was not performed). The role of the pharmacist present in hospital emergency services would be to recognize these cases, so that the best conducted could immediately be established, such as the administration of antidotes and establishment of schemes for withdrawal of the medications.

An important question to consider is the difficulty professionals have in recognizing an adverse event related to medications (ADR). This may, for example, result in the so-called "therapeutic cascade", in the case of adverse reaction or unidentified drug interaction, or in the aggravation of a situation, generating morbidity. A Canadian study was conducted with the purpose of verifying whether the doctors that attended in hospital emergencies routinely identified confirmed cases of ADR . The proportion of non identified ADR was 22\%; $53.6 \%$ of the cases that were not attributed to ADR were classified by the prescriptors as being "uncertain". The hypotheses raised as regards this result were: variation in the definition of the concept of ADR, need of time for attendance and information available about the patient, multifactorial cases ${ }^{36}$.

The results of this study could trace a profile of patients who seek the emergency services of HCPA, and estimate how many cases occurred due to MRM, in addition to which proportion would be avoidable. The findings point towards the possible failures in the process of use of medications, which is important for tracing strategies with the purpose of reducing problems related to medications, and consequently, to the appearance of morbidity related to them. 


\section{Conclusions}

The data obtained in this study show that $14.6 \%$ of interviewed patients sought hospital emergency department because of MRM and about $63 \%$ of these cases were considered preventable.

Presence of chronic diseases and use of potentially dangerous or low therapeutic index medications were characterized in this study as factors associated with the development of MRM.

The health care services must qualify the follow-up of patients with these factors. Thus, a portion of the demand for hospital emergencies could be avoided, since the problems related to medications associated with patients, mainly adhesion to treatment and lack of follow-up (observed as being the most frequent causes of MRM) could be identified and interventions performed.

Thus, the users would gain quality of life and better attendance by health professionals; the health services would work in the face of an expected demand; the health system as a whole, would have its resources adequately applied. Furthermore, these results can to base further studies in this area of knowledge.

\section{Collaborations}

MY Tramontina participated in the design, outline, data collect, data analysis and interpretation, writing of the paper and its critical review. MB Ferreira participated in the design and outline. MS Castro participated in the critical review of the paper. I Heineck participated in the design, outline, data analysis and interpretation, writing of the paper and its critical review. All participated in the approval of the version to be published.

\section{Acknowledgments}

MY Tramontina received a scholarship from FAPERGS/BR. 


\section{References}

1. Baena Parejo MI, Dáder MJF, Iglesias RM, Zurita AZ, Martin JJ, Olmos JM. Problemas de salud relacionados con los medicamentos en un servicio de urgencias hospitalario. Med Clin 2005; 124(7):250-255.

2. Baena MI, Marín R, Martínez Olmos J, Fajardo P, Vargas J, Faus MJ. Nuevos crietrios para determinar la evitabilidad de lós problemas relacionados com lós medicamentos. Uma revisión actualizada a partir de la experiência com 2.558 personas. Pharmaceutical Care España 2002; 4:3.

3. Baena MI, Faus MJ, Fajardo PC, Luque FM, Sierra F, Martinez-Olmos J, Cabrera A, Fernandez-Llimos F, Martinez-Martinez F, Jimenez J, Zarzuelo A. Medicine-related problems resulting in emergency department visits. Eur J Clin Pharmacol 2006; 62(5):387-393.

4. Beijer HJ, de Blaey CJ. Hospitalisations caused by adverse drug reactions (ADR):a meta-analysis of observational studies. Pharm World Sci 2002; 24(2):46-54.

5. Hepler CD, Segal R. Preventing medication errors abd improving drug outcomes - A management Systems Approach. Boca Raton: CRC Press; 2003.

6. Andreazza RS, Silveira de Castro M, Sippel Koche P, Heineck I. Causes of drug-related problems in the emergency room of a hospital in southern Brazil. Gac Sanit 2011; 25(6):501-506.

7. García V, Marquina I, Olabarri A, Miranda G, Rubiera G, Baena MI. Resultados negativos asociados con la medicación en un servicio de urgencias hospitalario. Farm Hosp 2008; 32(3):157-162.

8. Baena MI, Fajardo PC, Pintor-Marmol A, Faus MJ, Marin R, Zarzuelo A, Martinez-Olmos J, Martinez-Martinez F. Negative clinical outcomes of medication resulting in emergency department visits. Eur $J$ Clin Pharmacol 2014; 70(1):79-87.

9. Queneau P, Bannwarth B, Carpentier F, Guliana J-M, Bouget J, Trombert B, Leverve X, Lapostolle F, Borron SW, Adnet F, Assoc Pedagog Natl Enseignement T. Emergency department visits caused by adverse drug events - Results of a French survey. Drug Saf 2007; 30(1):81-88

10. McDonnell PJ, Jacobs MR. Hospital admissions resulting from preventable adverse drug reactions. Ann Pharmacother 2002; 36(9):1331-1336.

11. Grupo de Investigación en Atención Farmacêutica (CTS-131), Universidad de Granada (España), Grupo de Investigación en Farmacologia (CTS-164), Fundación Pharmaceutical Care España, Sociedad Espa ñola de Farmacia Comunitaria (SEFaC). Tercer Consenso de Granada sobre Problemas Relacionados con Medicamentos (PRM) y Resultados Negativos asociados a la Medicación (RNM). Ars Pharm 2007; 48(1):5-17.

12. Al-Olah YH, Al Thiab KM. Admissions through the emergency department due to drug-related problems. Ann Saudi Med 2008; 28(6):426-429.

13. Guerreiro MP, Cantrill JA, Pisco L, Martins AP. Considerations on preventable drug-related morbidity in Primary Care Part I - Impact of preventabledrug-related morbidity. Rev Port Clin Geral 2005; 21:269-279.

14. Patel P, Zed PJ. Drug-related visits to the emergency department: how big is the problem? Pharmacotherapy 2002; 22(7):915-923.
15. Dago Martínez A, Arcos González P, Toledo Saavedra FA, Baena Parejo MI, Martínez Olmos J, Gorostiza Ormaetxe Í. Indicadores de riesgo de morbilidad prevenible causada por medicamentos. Gac Sanit 2007; 21(1):29-36

16. Menéndez-Conde CP, Vicedo TB, Silveira ED, Accame EC. Resultados negativos asociados al uso de medicamentos que motivan ingreso hospitalario. Farm Hosp 2011; 35(5):236-243.

17. Medeiros Netto AS, Melo FB, Silva WB. Frecuencia de problemas relacionados con los medicamentos en pacientes que visitaron el servicio de urgencia de un hospital regional. Seguimiento Farmacoterapéutic 2005; 3(4):213-224

18. Tafreshi MJ, Melby MJ, Kaback KR, Nord TC. Medication-related visits to the emergency department: A prospective study. Ann Pharmacother 1999; 33(12):1252.

19. Baena M, Calleja M, Romero J, Vargas J, Zarzuelo A, Jimenez-Martín J, Faus M. Validación de un cuestionario para la identificación de problemas relacionados con los medicamentos en usuarios de un servicio de urgencias hospitalario. Ars Pharmaceutica 2001; 42(34):147-171

20. Naranjo CA, Busto U, Sellers EM, Sandor P, Ruiz I, Roberts EA, Janecek E, Domecq C, Greenblatt DJ. A method for estimating the probability of adverse drug reactions. Clin Pharmacol Ther 1981; 30(2):239-245.

21. Fernández-Llimós F, Faus MJ, Gastelurrutia MÁ, Baena MI, Tuneu L, Martinez Martínez F. Identificación sistemática de resultados clínicos negativos de la farmacoterapia. Seguimiento Farmacoterapéutic 2004; 2(3):195-205.

22. Kongkaew C, Hann M, Mandal J, Williams SD, Metcalfe D, Noyce PR, Ashcroft DM. Risk Factors for Hospital Admissions Associated with Adverse Drug Events. Pharmacotherapy 2003; 33(8):827-837.

23. Brasil. RDC No 67,8 de outubro de 2007. Dispõe sobre Boas Práticas de Manipulação de Preparações Magistrais e Oficinais para Uso Humano em farmácias. Diário Oficial da União 2007; 9 out.

24. Queiroz RA. Institute for Safe Medication Practices (ISMP). Belo Horizonte: Boletim ISMP Brasil; 2012.

25. Zed PJ. Drug-related visits to the emergency department. J Pharm Pract 2005; 18(5):329-335.

26. Al-Arifi M, Abu-Hashem H, Al-Meziny M, Said R, Aljadhey H. Emergency department visits and admissions due to drug related problems at Riyadh military hospital (RMH), Saudi Arabia. Saudi Pharm J 2014; 22(1):17-25.

27. Howard RL, Avery AJ, Howard PD, Partridge M. Investigation into the reasons for preventable drug related admissions to a medical admissions unit: observational study. Qual Saf Health Care 2003; 12(4):280-285.

28. Leendertse AJ, Egberts ACG, Stoker LJ, van den Bemt PMLA, Grp HS. Frequency of and risk factors for preventable medication-related hospital admissions in the Netherlands. Arch Intern Med 2008; 168(17):18901896.

29. Martín MT, Codina C, Tuset M, Carné X, Nogué S, Ribas J. Problemas relacionados con la medicación como causa del ingreso hospitalario. Med Clin 2002; 118(6):205-210. 
30. Souza TTD. Morbidade e Mortalidade Relacionadas a Medicamentos: Revisão Sistemática e Meta-análise de Estudos Observacoionais - PR [dissertação]. Curitiba: Universidade Federal do Paraná; 2013.

31. Gomes RRFM, Machado CJ, Acurcio FA, Guimaraes MDC. Pharmacy records as an indicator of non-adherence to antiretroviral therapy by HIV-infected patients. Cad Saude Publica 2009; 25(3):495-506.

32. Alomar MJ. Factors affecting the development of adverse drug reactions (Review article). Saudi Pharm J 2014; 22 (2):83-94.

33. Takahashi PSK, Sousa AB, Storpirtis S. Evaluation of negative outcomes associated with medication (NOM) by pharmacists at a home assistance programme in a Brazilian teaching hospital. Farm Hosp 2011; 35 (6):316.e311-316.

34. Huri HZ, Wee HF. Drug related problems in type 2 diabetes patients with hypertension: a cross-sectional retrospective study. BMC Endoc Disord 2013; 13:2.

35. Oenning D, Oliveira BV, Blatt CR. Patient awareness about drugs prescribed after medical appointment and prescription. Cien Saude Colet 2011; 16(7):3277-3283.

36. Hohl CM, Zed PJ, Brubacher JR, Abu-Laban RB, Loewen PS, Purssell RA. Do Emergency Physicians Attribute Drug-Related Emergency Department Visits to Medication-Related Problems? Ann Emerg Med 2010; 55(6):493-502.

Artigo apresentado em 04/04/2016

Aprovado em 20/07/2016

Versão final apresentada em 22/07/2016 